\title{
Proses Penyampaian Pesan Kampanye Internal Greget Plastik untuk Menumbuhkan Kesadaran Karyawan dalam Mengurangi Penggunaan Plastik Sekali Pakai (Studi pada PT Kalbe Farma Tbk)
}

\author{
Jessica Donata, Yugih Setyanto \\ jessica.915160012@stu.untar.ac.id,yugihs@fikom.untar.ac.id
}

Fakultas Ilmu Komunikasi Universitas Tarumanagara

\begin{abstract}
Indonesia is currently ranked the second highest in the world as one of the countries that contributes the most plastic waste. Now many companies have proven this fact and supported a campaign to use plastics that have been used, one of which is PT Kalbe Farma Tbk. The research objective is to explain the process and communication strategies used in greget plastik campaigns. The method used in this research is a qualitative research method by studying case studies. Data collection techniques are done by interview, observation and documentation. Source triangulation is done to use the validity of the data used. This research shows that the communication strategies used in greget plastik campaigns invite communication processes, such as communication, messages, audiences, media, and effects. Related to the communication process carried out in a greget plastik campaign consisting of awareness, attitudes and opinions, and behavior, where employees are given information and facts in the field regarding plastics. Then employees are invited to be directly involved in the campaign, so they can change their habits.
\end{abstract}

Keywords: campaign, communication process, greget plastik.

\begin{abstract}
Abstrak
Saat ini Indonesia menempati peringkat kedua tertinggi di dunia sebagai salah satu negara yang menyumbang sampah plastik terbanyak. Kini banyak perusahaan yang telah menyadari fakta tersebut dan berupaya menerapkan gerakan kampanye untuk mengurangi penggunaan plastik sekali pakai, salah satunya adalah PT Kalbe Farma Tbk. Tujuan penelitian untuk menjelaskan proses dan strategi komunikasi yang digunakan kampanye greget plastik. Dalam penelitian ini penulis menggunakan metode penelitian kualitatif deskriptif. Teknik pengumpulan data dilakukan dengan wawancara, observasi, dokumentasi, dan studi kepustakaan. Triangulasi sumber dilakukan untuk menguji keabsahan data yang digunakan. Penelitian ini membahas proses penyampaian pesan yang digunakan dalam kampanye greget plastik, antara lain melibatkan unsur-unsur proses komunikasi, seperti komunikator, pesan, khalayak, media, dan efek. Adapun pelaksanaan proses komunikasi yang dilakukan dalam kampanye greget plastik berupa awareness, attitudes and opinion, dan behavior, di mana karyawan diberi informasi dan fakta-fakta di lapangan seputar plastik. Kemudian karyawan diajak untuk terlibat langsung dalam kampanye, sehingga dapat mengubah kebiasaan mereka.
\end{abstract}

Kata Kunci : greget plastik, kampanye, proses komunikasi.

\section{Pendahuluan}

Saat ini Indonesia menempati peringkat kedua tertinggi di dunia sebagai salah satu negara yang menyumbang sampah plastik terbanyak. Kini banyak perusahaan yang telah menyadari fakta tersebut dan berupaya menerapkan gerakan kampanye 
untuk mengurangi penggunaan plastik sekali pakai, salah satunya adalah PT Kalbe Farma Tbk. Dalam hal ini peran seorang Public Relations dibutuhkan untuk merencanakan kampanye sosial bagi institusinya atau perusahaannya. Upaya tersebut dilakukan agar reputasi perusahaan tetap terjaga, serta dapat menjalin hubungan yang baik dengan para pemangku kepentingan (stakeholder).

Saat ini penulis melihat bahwa banyak perusahaan-perusahaan yang ikut menggaungkan kampanye untuk menjaga lingkungan. Maka penulis tertarik untuk mempelajari strategi komunikasi dalam kampanye perusahaan. PT Kalbe Farma Tbk. merupakan perusahaan yang bergerak di bidang kesehatan. Maka dari itu, perusahaan juga peduli dengan kesehatan dan kesejahteraan karyawan-karyawannya. Selain itu topik permasalahan lingkungan ini menjadi topik yang sering dibahas di media.

Menurut Eko Harry (2013) fungsi media untuk menyebarkan pesan kepada khalayak luas, hal ini lah yang menjadi alasan utama mengapa institusi atau organisasi peduli terhadap lingkungan. Media digunakan sebagai alat untuk menyuarakan pentingnya penyelamatan bumi dari kerusakan. Pola komunikasi penyelamatan lingkungan, harus mampu bersaing dengan program yang mengeksplorasi hiburan yang lebih digemari masyarakat. Tujuannya jelas, agar pesan mudah diingat, dan masyarakat mau berpartisipasi dalam mendukung program penyelamatan lingkungan, dari berbagai ancaman kerusakan, pencemaran dan kepunahan.

Dari latar belakang tersebut, maka penulis berminat untuk melakukan penelitian yang berjudul "Proses Penyampaian Pesan Kampanye Internal Greget Plastik untuk Menumbuhkan Kesadaran Karyawan dalam Mengurangi Penggunaan Plastik Sekali Pakai (Studi pada PT Kalbe Farma Tbk)".

Pada penelitian ini penulis menggunakan teori komunikasi menurut Harold D. Laswell, yang berbunyi "Who says what in which channel to whom with what effect") dan teori proses komunikasi kampanye menurut Gregory (2010:90-91), yaitu awareness, attitudes and opinion, dan behavior.

Adapun tugas seorang Public Relations diantaranya untuk menjaga hubungan dengan khalayaknya di perusahaan, termasuk kegiatan yang menjadi tanggung jawab sosial perusahaan. Menurut Jefkins (2003) "Public relations adalah semua bentuk komunikasi yang terencana, baik itu kedalam maupun keluar, antara suatu organisasi dengan semua khalayaknya dalam rangka mencapai tujuan-tujuan spesifik yang berlandaskan pada saling pengertian". Adapun bentuk tanggung jawab sosial yang wajib dilakukan oleh sebuah perusahaan,yaitu tanggung jawab sosial kepada konsumen, tanggung jawab sosial kepada karyawan, tanggung jawab sosial kepada pemegang saham, dan tanggung jawab sosial kepada lingkungan.

Pengertian kampanye public relations menurut yaitu bertujuan meningkatkan kesadaran dan pengetahuan khalayak sasaran untuk menarik perhatiannya serta menumbuhkan opini yang positif terhadap suatu kegiatan baik di organisasi atau institusi agar tercipta suatu kepercayaan dan citra yang baik di mata masyarakat melalui penyampaian pesan secara intensif dengan proses komunikasi yang berkelanjutan. Menurut Gregory (2010) proses penyampaian pesan atau informasi dalam komunikasi kampanye dilakukan melalui tiga proses, yaitu Awareness, Attitudes and Opinion, dan Behaviour. Pertama dengan cara melibatkan publik atau khalayak sasaran dalam sebuah kampanye. Ini merupakan proses awal, di mana khalayak akan menjadi sadar dengan pesan yang disampaikan dalam kampanye. Selain itu perlunya pemberian informasi secara berulang-ulang agar khalayak mampu mengingat pesan dalam kampanye tersebut. Setelah itu barulah dapat dibentuk 
kebiasaan atau pandangan baru. Pada proses ini bisa terjadi penerimaan maupun penolakan dari khalayak. Artinya bergantung pada respon khalayak. Behaviour berarti mempromosikan tindakan yang harus dilakukan, seperti memberi contoh teladan, agar orang lain tertarik untuk mengikuti tindakan tersebut.

\section{Metode Penelitian}

Penulis menggunakan pendekatan penelitian kualitatif deskriptif, yaitu penelitian yang dapat mendeskripsikan hasil pengamatan dari penulis ataupun faktafakta yang ditemukan di lapangan selama proses observasi. Penelitian Kualitatif ini dapat berupa kata-kata yang tertulis maupun lisan dari perilaku informan yang dapat diamati penulis. Jenis metode penelitian yang digunakan penulis adalah studi kasus artinya bahwa penulis mendeskripsikan hasil penelitian dan berusaha merangkumnya sesuai dengan keadaan yang benar-benar terjadi. Menurut K. Yin (2013) studi kasus adalah suatu pengalaman dengan menyelidiki fenomena yang ada di dalam konteks kehidupan nyata.

Subjek penelitian menurut Arikunto (2010:152) merupakan sesuatu yang sangat penting kedudukannya di dalam penelitian. Subjek penelitian dapat berupa benda, hal, atau orang. Subjek dalam penelitian ini adalah divisi Internal Communications PT Kalbe Farma Tbk yang berkaitan langsung dengan kampanye greget plastik beserta karyawan yang menjalankan kampanye tersebut. Sedangkan objek penelitian dalam penelitian kualitatif yang diobservasi menurut Spradley dinamakan situasi sosial, yang terdiri atas tiga komponen yaitu place (tempat), actor (pelaku), dan activities (aktivitas). (Sugiyono, 2015:229). Objek dalam penelitian ini adalah strategi dan proses komunikasi dalam kampanye greget plastik.

Pada penelitian ini penulis mengumpulkan data-data dengan cara: (1). Observasi adalah kemampuan seseorang untuk menggunakan pengamatannya melalui hasil kerja panca indra mata serta dibantu dengan pancaindra lainnya (Burhan, 2017:115). (2). Wawancara merupakan pertemuan dua orang untuk bertukar informasi dan ide melalui tanya jawab, sehingga dapat dikonstruksikan makna dalam suatu topik tertentu. Esterberg, dalam Sugiyono (2013:233) mengemukakan beberapa macam wawancara yaitu wawancara testruktur, wawancara semiterstruktur, dan wawancara tidak terstuktur. (3). Dokumentasi merupakan proses pencatatan peristiwa yang sudah berlalu. Dokumen bisa berbentuk tulisan, gambar, atau hasil karya seseorang.

\section{Hasil Temuan dan Diskusi}

PT Kalbe Farma Tbk. merupakan perusahaan yang berpusat di Cempaka Putih, Jakarta Pusat, perusahaan ini terlah berusia 53 tahun di Indonesia. Perusahaan ini membuat sebuah kampanye yang ditargetkan untuk kalangan internal mereka, yaitu karyawan Kalbe. Kampanye ini kemudian diberi nama "greget plastik" berdasarkan hasil diskusi dengan pihak manajemen. Periode pelaksanaan kampanye yaitu mulai dari bulan Maret 2019 sampai dengan September 2019. Dimulai dengan acara Kick Off yang dihadiri oleh Presiden Komisaris PT Kalbe Farma Tbk., Bernadette Ruth Irawati Setiady. 
Berawal dari munculnya regulasi pelarangan penggunaan plastik sekali pakai oleh menteri Susi Pudjiastuti yang kemudian ingin diterapkan di lingkungan perkantoran Kalbe Group. Kampanye greget plastik yang berhasil ini diharapkan dapat masuk ke dalam sustainability report perusahaan. Sustainability Reporting yaitu pelaporan yang dilakukan oleh suatu perusahaan untuk mengukur, menjelaskan, serta menampilkan kemajuan perusahaan kepada pemangku kepentingan (stakeholders) yang bertujuan agar kinerja perusahaan turut serta dalam pembangunan yang berkelanjutan. Biasanya perusahaan-perusahaan yang telah go public memiliki kewajiban untuk membuat laporan keberlanjutan sesuai dengan Pasal 66 Ayat 2 Undang-Undang No. 40 Tahun 2007 tentang Perseroan Terbatas.

Tim pelaksana dalam kampanye greget plastik ini yaitu divisi Internal Communications bekerja sama dengan divisi General Affairs dan divisi Keselamatan Kesehatan Kerja dan Lingkungan (K3L). Hal yang dilakukan dengan mengubah kebiasaan karyawan-karyawan Kalbe terhadap lima macam benda yaitu, (tumbler, sendok garpu stainless, sedotan stainless, tempat makan, dan totebag). Gerakan ini tidak dilaksanakan semua secara langsung tetapi dibagi ke dalam tahap lima bulan selama periode kampanye greget plastik setelah acara Kick Off. "Kita setiap bulan ganti-ganti lima macam gerakannya, pertama tumbler, lalu tempat makan, sedotan stainless, sendok dan garpu stainless, terakhir totebag".

Media komunikasi yang digunakan dalam kampanye greget plastik antara lain: media sosial di Instagram, media cetak berupa X-Banner, Spanduk, dan Poster, media kampanye lainnya, seperti desain baju kaos. Sasaran khalayak dalam kampanye greget plastik adalah karyawan internal di Kalbe Group. Pada awalnya ditargetkan kepada 20 perusahaan yang tergabung dalam Kalbe Group, namun pada realisasinya kampanye greget plastik berhasil dilaksanakan di 15 perusahaan yang berada di 18 lokasi.

Tujuan dari kampanye greget plastik ada dua macam. Pertama, menumbuhkan kesadaran karyawan terhadap lima benda (tumbler, sendok garpu stainless, sedotan stainless, tempat makan, dan totebag) sebelum kampanye dan setelah kampanye. Kedua, perbedaan berat sampah plastik sebelum kampanye dan setelah kampanye.

Kampanye greget plastik ini dimulai dengan menyebarkan kuesioner mengenai kesadaran karyawan terhadap penggunaan plastik sekali pakai. Kemudian diakhiri juga dengan menyebarkan kuesioner dengan pertanyaan yang kurang lebih sama, untuk mengukur tingkat kesadaran karyawan terhadap penggunaan plastik sekali pakai.

Strategi kampanye yang digunakan dalam kampanye greget plastik, yaitu awareness, attitudes and opinion, dan behaviour. Awareness artinya bahwa karyawan distimulasi dengan fakta-fakta seputar plastik yang mendorong karyawan sehingga berpikir lebih jauh dan menyadari tentang permasalahan yang ada. Attitudes and opinion artinya menarik atensi karyawan dengan cara mengembangkan inisiatif dan kreativitas dari karyawan yang terlibat dalam kampanye ini. Behaviour artinya bahwa karyawan diajak terlibat langsung dalam kampanye greget plastik. Setiap bulan mengganti kebiasaan dengan lima macam benda, yaitu (tumbler, sendok garpu stainless, sedotan stainless, tempat makan, dan totebag). 
Divisi-divisi yang terlibat dalam pelaksanaan kampanye greget plastik berharap bahwa kampanye ini tidak hanya berhenti disini, melainkan dapat menjadi "budaya baru" di Kalbe Group. Kesadaran karyawan untuk meminimalisir penggunaan plastik sekali pakai akan terus dipelihara dan dibina. Sehingga kampanye greget plastik dapat berdampak juga ke masyarakat.

Kampanye greget plastik menjadi salah satu program yang dilaksanakan PT Kalbe Farma Tbk. untuk menumbuhkan kesadaran karyawannya dalam meminimalisir penggunaan sampah plastik. Divisi-divisi yang terlibat dalam pelaksanaan kampanye greget plastik berencana untuk melanjutkan kampanye yang sudah berjalan ini, tentunya untuk skala yang lebih besar membutuhkan kerja sama dengan pihak lainnya.

\section{Simpulan}

Berdasarkan hasil penelitian dan pembahasan yang telah disusun oleh penulis, maka dapat disimpulkan bahwa strategi komunikasi yang digunakan melibatkan unsur-unsur proses komunikasi, seperti komunikator, pesan, khalayak, media, dan efek. Adapun proses penyampaian pesan yang digunakan dalam kampanye greget plastik yaitu awareness, attitudes and opinion, dan behaviour.

Awareness artinya bahwa karyawan distimulasi dengan fakta-fakta seputar plastik yang mendorong karyawan sehingga berpikir lebih jauh dan menyadari tentang permasalahan yang ada. Attitudes and opinion artinya menarik atensi karyawan dengan cara mengembangkan inisiatif dan kreativitas dari karyawan yang terlibat dalam kampanye ini. Behaviour artinya bahwa karyawan diajak terlibat langsung dalam kampanye greget plastik. Setiap bulan mengganti kebiasaan dengan lima macam benda, yaitu (tumbler, sendok garpu stainless, sedotan stainless, tempat makan, dan totebag). Sehingga karyawan melaksanakan kampanye greget plastik dengan antusias dan sukarela.

\section{Ucapan Terimakasih}

Ucapan terimakasih ditujukan kepada Tuhan Yang Maha Esa, Orang tua, Whisnu Thomas Julianto selaku HR \& Operation Senior Manager di PT Kalbe Farma Tbk. yang telah membantu mengenalkan penulis kepada narasumbernarasumber. Bernadette Fanny, Devina Vania Tertia, Maptuh, Bagus Supriyono, dan Koes Hendrawan Bramasto selaku narasumber saya yang telah menyempatkan waktu dan berkenan untuk bekerjasama selama proses penelitian ini. Selain itu penulis juga ingin berterima kasih kepada Fakultas Ilmu Komunikasi Universitas Tarumanagara tempat di mana penulis menimba ilmu yang nantinya akan berguna di tahap kehidupan selanjutnya, serta teman-teman penulis yang telah banyak membantu penulis dalam menyelesaikan penelitian ini.

\section{Daftar Pustaka}

Arikunto, Suharsimi. (2010). Prosedur Penelitian Suatu pendekatan Praktek. Jakarta: Rineka Cipta.

Gregory, Anne. (2010). Planning and Managing Public Relations Campaign, A Strategy Approach. London: Kogan Page. 
Vol. 4, No. 2, Oktober 2020, Hal 245 - 250

Jefkins, Frank. (2003). Public Relations Edisi kelima, Jakarta: PT Gelora Aksara Pratama

Sugiyono. (2013). Metode Penelitian Kuantitatif, Kualitatif, dan R\&D. Bandung: CV. Alfabeta.

Yin, Robert K. (2013). Studi Kasus Desain \& Metode. Jakarta: PT. Raja Grafindo Persada. 